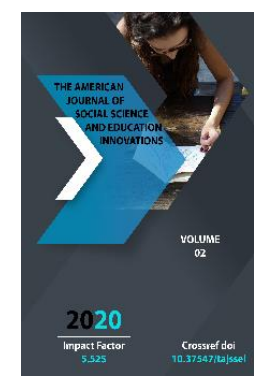

Copyright: Original content from this work may be used under the terms of the creative commons attributes 4.0 licence.

\section{The Importance Of Interdisciplinary Integration In Preparing Future Vocational Education Teachers For Professional Activities}

Kakhramon Tanzilovich Olimov

Doctor Of Pedagogical Sciences, Professor, Ministry Of Preschool Education, Uzbekistan

Shahlo Sadullaevna Sharipova

Doctor Of Philosophy Phd, Institute For Retraining And Advanced Training Of Preschool Education Personnel And Managers, Uzbekistan

\title{
ABSTRACT
}

This article highlights the importance of interdisciplinary integration in preparing future vocational education teachers for professional work, interdisciplinary relationships, mechanisms for forming professional competencies in the development of student learning activities, and pedagogical conditions for effective interdisciplinary integration. The emphasis is placed on systematic inclusion of university teachers in achieving the goals and objectives of building professional competence of students through interdisciplinary integration.

\section{KEYWORDS}

Interdisciplinary, interdisciplinary integration, professional activities, educational activities, professional competence.

\section{INTRODUCTION}

Didactic conditions for integration of theoretical and practical knowledge are internally specific (psychologicallypedagogical) disciplines for the content and process of vocational training, not their special organization, creation, implementation, but actualization of students in the learning process, ie teacher. The purpose of organizing the process of acquiring knowledge by students is to make it a goal for students to acquire pedagogical knowledge, while the didactic units of content are taught by students in a personal, to be able to assess the level of impact of theoretical and practical knowledge, to predict the applicability of general professional (psycho-pedagogical) knowledge in practical activities.

It is argued that interdisciplinary links are established at the level of related concepts, 
topics, departments, and contribute to a more intelligent acquisition of knowledge by students. However, they do not provide systematic links. Experience testing of interdisciplinary capabilities did not lead to significant changes in both the level of knowledge acquisition, the nature of learning motivations, and the level of development of the individual. According to the same author, he first came up with the concept of interrelationships between general and vocational education, which is provided not only by means of interdisciplinary communication but also by the application of private principles: polytechnic, interpersonal, vocational, problematic and more. However, despite some successes, students' knowledge, skills and qualifications have not significantly increased. Then the third hypothesis emerges: a qualitatively new level of vocational education can be achieved in the context of a holistic educational process based on integration and knowledge differentiation, meaningful generalization, the principle of 'enlarged units' and 'technological principles'. Integration of general and special knowledge is an important condition for improving vocational education.

\section{MATERIAL AND METHODS}

We have considered interdisciplinary integration in pedagogy-based academic education, networking and integration in industry:

a) Identification of requirements for the organization of the educational process and the integration of key impacts in a set of pedagogical conditions, and the specifics of the students and the educational institution are developed at the interest of the students; b) Integrated approaches to the problem of integration are developed at the level of pedagogical phenomena: meaningful, based on the interdisciplinary system of learning disciplines, where integration is subject to learning content, and procedural, where attention is focused on forms, methods and means of learning;

c) Integrated learning process, along with its main objectives, is a way of optimizing the learning process as a means of enhancing the effectiveness and reliability of the learning process, such as the complementarity and integration of elements of learning in one subject.

\section{RESULTS AND DISCUSSION}

Improvement of preparation of future teacher of professional education for professional activity The pedagogical conditions for effective implementation of interdisciplinary integration were identified and justified:

- To consider the professional orientation of the specialist as the cornerstone of an integrative approach with significant, meaningful, functional and structural characteristics;

- Designing a model for improving the professional training of future vocational education teachers based on a complementary order based on the purpose, content, technology and outcomes of education integration;

- Student (person) - a gradual, ever-changing process that allows students to move from academic to professional-focused activities within educational technology.

- We have developed a process of integrating pedagogical and special (technical) disciplines in order to implement an 
integrative approach to the diagnosis of vocational training (Figure 1).

Stage 3:

Metapredmet

Stage 2:

Interdisciplinary

Relations
The use of metaprotechnical relationships: the formation and development of students' knowledge and skills, and the dynamic interdependence of metaphorical communication in the pedagogical and special disciplines that reflect an objective system.

Communication theory and actual practice (true ...) allow students to effectively change their learning activities by the nature of their activities - in this case they have the opportunity to implement independent and professional algorithms. At this stage, a system of professional competences will

The use of interdisciplinary communication: the formation of students' knowledge and skills, the implementation of interdisciplinary relationships in pedagogical disciplines, which combine disciplinary (disciplinary) and industry (industry) disciplines that reflect an important aspect of real practice.

Important modeling in pedagogical practice enables students to change their reproductive cognitive activity: in this case, the student has the ability to search for himself and perform algorithms of cognitive activity with the help of the teacher's fragmentary advice. cognitive activity is partly productive. productive learning activities of students partial productive (effective) learning activities of students 


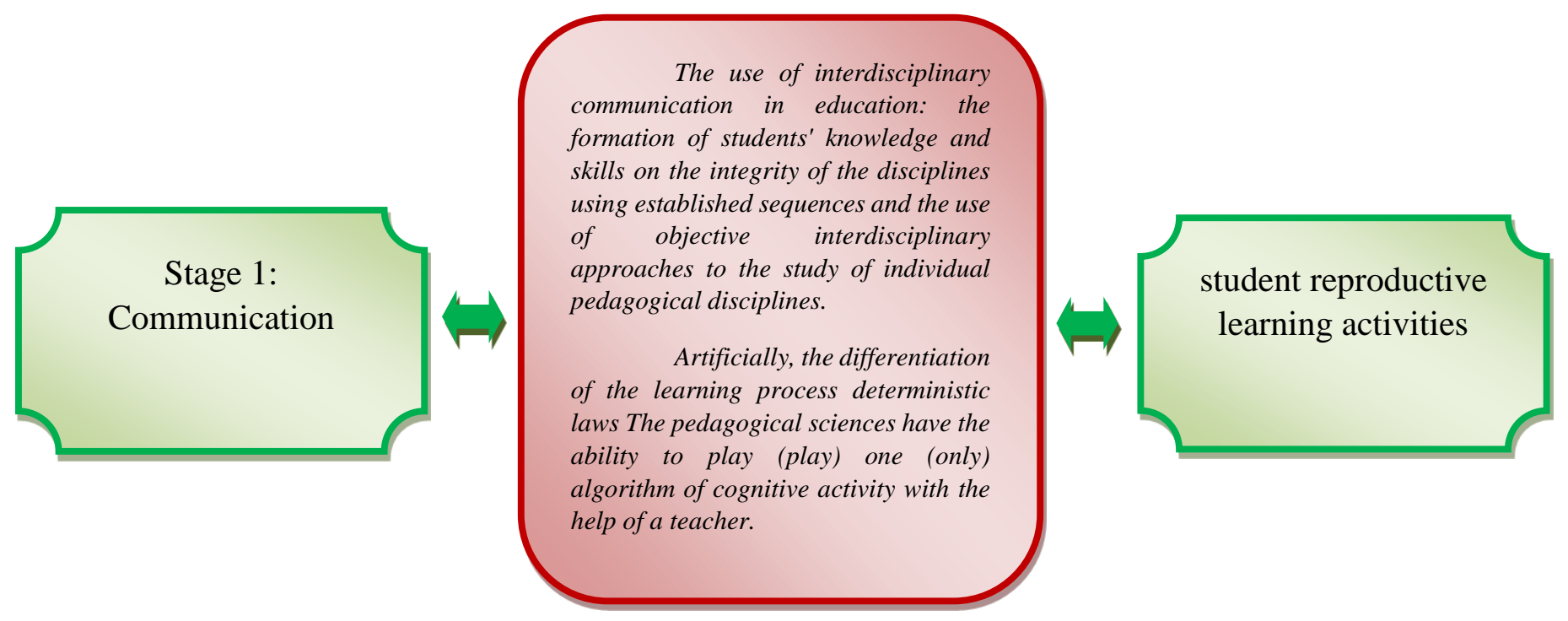

Figure 1. The process of integration of pedagogical and technical (special) disciplines

In order to achieve the stated goals and objectives of the professional competence of students through interdisciplinary integration, teachers of higher education institutions should carry out this work systematically.

\section{Interaction:}

a) The basis for the concrete implementation of the general integration ideas in the theory and practice of pedagogy;

b) Provide a specially created pedagogical environment for the development of pedagogical integration:

c) provide an orientation to the effective integration process, supplement it with specific pedagogical content;

d) Defines the initial structure and content of the integration processes.

In turn, integration:

a) The modern education system is one of the ultimate logical forms of interconnection as a development law; b) Show common trends in interconnectedness, thereby facilitating the modernization of problem-solving;

c) The boundary of restructuring the relationship.

Based on the process of integration of pedagogical and special disciplines, this is a special knowledge of pedagogical element integration. This approach implies the transition to independent learning programs and courses, with the use of pedagogical elements to integrate interdisciplinary tasks into three levels: interdisciplinary, interdisciplinary, metapredmet.

Reading, using in their own experiences, acting on analogies, using acquired knowledge and skills will increase the effectiveness of training.

The feature of integrative courses is not only to provide students with empowerment in their teaching activities, but also to enhance student activity in cognitive activity, to integrate the 
content of vocational education content into the concept of life-to-student education. This concept develops a person-centered learning approach that allows the student to identify characteristics as a subject of this process, the recognition of the uniqueness and self-worth of subjective experience of the learners, and the pedagogical interaction based on this subjective experience.

In conclusion, it is important to note that the effective (broad) integration of pedagogical and technical disciplines into the educational process in higher education institutions involves three stages that reflect the nature of the relationship between the social and pedagogical needs, and the integration of pedagogical and special disciplines. Due to the apparent lack of application of it in pedagogical practice, this can be substantially allowed during the process model (Figure 1).

The first stage is the use of interdisciplinary communication in education: the formation of students' knowledge and skills on the integrity of the disciplines using established sequences, and the use of objective interdisciplinary approaches to the study of individual pedagogical disciplines.

Determine laws of the differentiation of learning process The pedagogical sciences have the ability to play (play) one (only) the algorithm of cognitive activity with the help of a teacher - the reproductive nature of the student's cognitive activity.

At this stage, a system of competences for learning activities will develop.

The second stage is the use of interdisciplinary communications: the formation of students' knowledge and skills, the implementation of interdisciplinary links in pedagogical disciplines that reflect an important aspect of real practice - a systematic (consistent organization) and specialized (field) disciplines.

Important modeling in pedagogical practice enables students to change their reproductive cognitive activity: in this case, the student has the ability to search for himself and perform algorithms of cognitive activity with the help of the teacher's fragmentary advice. cognitive activity is partly productive.

At this stage, professional competence begins to form.

The third stage is the use of interdisciplinary connections: the formation and development of students' knowledge and skills, and the dynamic interconnection of metaprotechnical and specialized disciplines that reflect an objective system. At this stage, a system of professional competences will be developed for students.

The effectiveness of the integration of pedagogical and specialized disciplines depends on the gradual introduction of interdisciplinary, interdisciplinary and metaprotechnical communications that allow the teacher to use active teaching and learning methods to develop a set of pedagogical skills, to update pedagogical tasks and, consequently, to produce them. gives. The only interdisciplinary approach is the difficulty in identifying student knowledge assessments between the humanities, general and special cycle disciplines. That is, the level of students' knowledge may not be sufficient for the study of the humanities and general departments. Therefore, this knowledge is necessary for faculty members not only to develop a cycle of curriculum for content development, but also to assess knowledge and skills. Throughout the educational process, professional competence 
through observation has been formed and implemented at various stages of acquiring sufficient knowledge.

\section{CONCLUSIONS}

Thus, professional activities and interdisciplinary integration are justified, provided that higher education institutions provide integration of undergraduate and undergraduate students with the integrated use of practical tasks in practice, only practical training will enhance the knowledge gained in the study of theoretical material. The student receives the necessary practical skills for successful professional activity by solving a complex learning task while doing any laboratory work.

\section{REFERENCES}

1. Ismailova Z.K., Khimmataliev D.A. Formation of student's scientific and creative abilities through problem education. // Irrigation and reclamation. No. 1. - pp.103-105.

2. Ismailova Z.K., Khimmataliev D.O. The role of pedagogical technology of multilevel education in modern professional education / The Seventh International Congress on Social Science sand Humanities, 2nd April, 2016, Vienna 2016, pp. 76-79.

3. Izmailova Yu.M. Integration of theoretical and practical psychological and pedagogical knowledge as a means of improving the training of future educational engineers: Dis. Cand. ped sciences / Yu.M. Izmailova. Saratov, 2006 .- 173 p.

4. Muslimov N.A. Theoretical-methodological bases of professional formation of teacher of vocational education. Diss... ped. f. d. - T.: 2007. - $315 \mathrm{p}$.

5. Olimov K., Abdukudusov O., Uzoqova L. and others. Methods of professional education. - T .: Finance, 2006. - 175 p.

6. Olimov K.T. Theoretical-methodological bases of creating a new generation of educational literature on special subjects: Dis. ... Ped. science. doc. - Tashkent: 2005. $286 \mathrm{p}$.

7. Olimov K.T., Avlyakulov N.H. Rustamov R. Module System of Teaching Vocational Sciences // Vocational Education. - 2003. No. 2. -18 p.

8. Khimmataliev D.O. Integration of pedagogical and technical knowledge in the preparation of professional activities. Monograph. - Tashkent: Uzbekistan, 2018. $168 \mathrm{p}$.

9. Odilov, B. A., \& Karimov, N. R. (2020). ANALYSIS OF TARGETED RESEARCH IN 2030 YEARS OF THE XX CENTURY. PalArch's Journal of Archaeology of Egypt/Egyptology, 17(6), 8887-8893.

10. Salima Rustamiy. (2020). scientific and theoretical content of the science of balāğat. Journal of Critical Reviews, 7(6), 132-137. 